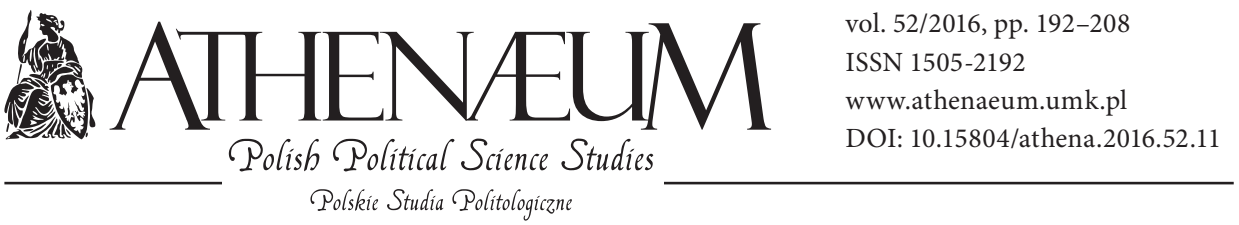

\title{
HUMAN DIGNITY IN THE EUROPEAN PERSPECTIVE AND THE PROPORTIONALITY PRINCIPLE
}

\author{
LUDZKA GODNOŚĆ W PERSPEKTYWIE EUROPEJSKIEJ \\ A ZASADA PROPORCJONALNOŚCI
}

Monika Forejtová*

\begin{abstract}
The fundamental human right to dignity is the cornerstone of European legal culture. The right has been provided for in international, European, and national legal instruments. Its role as a benchmark reference for all other human rights has developed into a self-standing and self-executing right, especially under the new EU Charter of Fundamental Rights. This evolution from the traditional role of the right to dignity is analysed in case study based on a real case before the Constitutional Court of the Czech Republic in 2015. The analysis brings forward a reflection about the need to respect the concept of dignity and how it actually is observed in the European context.
\end{abstract}

Keywords: human rights, human dignity, rights of the child, social rights, proportionality principle, constitutional justice, European Court of Human Rights
ABSTRAKT

Podstawowe prawo człowieka do godności jest kamieniem węgielnym europejskiej kultury prawnej. Prawo to zostało przewidziane w międzynarodowych, europejskich i krajowych instrumentach prawnych. Jego rola jako punktu odniesienia dla wszystkich innych praw człowieka rozwijała się w kierunku prawa autonomicznego i samowykonywalnego, w szczególności w ramach nowej unijnej Karty praw podstawowych. Ta ewolucja tradycyjnej roli prawa do godności jest analizowana w studium przypadku opartym na sprawie toczonej przed Trybunałem Konstytucyjnym Republiki Czeskiej w 2015 roku. Analiza prowadzi do refleksji o konieczności respektowania pojęcia godności, jakie faktycznie obserwuje się w skali europejskiej.

Słowa kluczowe: prawa człowieka, godność człowieka, prawa dziecka, prawa socjalne, zasada proporcjonalności, sprawiedliwość konstytucyjna, Europejski Trybunał Praw Człowieka

* University of West Bohemia, Department of Constitutional and European Law. 


\section{INTRODUCTION}

International but also domestic legal instruments bring forth the concept of human dignity, which strives to embody the all-embracing foundation for functioning of the society, in which the state cannot behave in breach of the immanent category of human dignity. The evolution of a modern state in the $19^{\text {th }}$ and the first half of the $20^{\text {th }}$ century has transformed our ethical perception of the positive law and also of justice as the cornerstones for functioning of the modern society, which became oriented towards securing the principles of justice and fairness. In the wake of World War II, the concept of human dignity expanded into the constitutional orders of various countries around the globe (Schultziner, Carmi, 2014, p. 461-490), also under the influence of the Universal Declaration of Human Rights (1948), which concerns human dignity already in its Preamble, and its Articles 1,2,22, and 23. Pursuant to this Declaration, human dignity is inherently common to all human beings, thus it is not a right granted (by any state), but rather recognised (Wagnerová, Šimíček, Langášek, Pospíšil, 2012, p. 55; Neal, 2014). The Universal Declaration takes human dignity for the foundations of freedom, justice and peace in the world. Such recognition does not, however, mean establishment of the right to dignity, but rather it encompasses the active duty of the state not to interfere with this fundamental right of each individual. The right to dignity was further embraced by the European Convention on Human Rights (1950) (Kmec, Kosař, Kratochvíl, Bobek, 2012, p. 864), which in its Protocol No. 13 abolishing the capital punishment (Novotný, 2014, p. 371; Repík, 2002) expressly provides for the necessity to fully recognize the unalienable dignity of every human being in all circumstances. The right to dignity is moreover included in the International Covenant on Civil and Political Rights (the Preamble and Article 10) and the International Covenant on Economic, Social and Cultural Rights (the Preamble and Article 13), in the UN Convention on the Rights of Persons with Disabilities, the Convention on the Rights of the Child, and the Convention for the Protection of Human Rights and Dignity of the Human Being with regard to the Application of Biology and Medicine (Convention on Human Rights and Biomedicine) (Düwell, Braarvig, Brownsword, Mieth, 2014).

A breakthrough legal framework on human life in dignity is envisaged in the Charter of Fundamental Rights of the European Union, which thanks to the Lisbon Treaty (Forejtová, Tronečková, 2011, p. 23, 81) gained the status of an EU primary law instrument. In its Title I (Dignity), and Article 1 (Human 
Dignity), the dignity is presented in the structure of the most advanced human rights document straight at the top and framed in language as follows: "Human dignity is inviolable. It must be respected and protected" (Forejtová, 2013, p. 78; Tomášek, Týč, 2013, p. 325; Klíma, 2011, p. 379). It is, however, proper to point out that the Court of Justice of the European Union ruled on the question of dignity right after the Charter of Fundamental Rights was adopted in Nice (2000), which the present Charter of Fundamental Rights of the EU has been drafted upon (2009). In the case Netherlands $v$ the European Parliament and the Council', a case concerning the challenge to the Directive of the European Parliament and the Council No. 98/44/EC on the legal protection of biotechnological inventions, in which the human body could fall within the scope of an invention, the Court of Justice ruled that the fundamental right to human dignity is an essential part of the European Union law. In its broader concept, human dignity comprises not only the physical manifestation of a human being, but also its psychical integrity. From the Explanations relating to the Charter of Fundamental Rights, discussing the amendments done by the Lisbon Treaty (2007/C 303/02), it is clear that none of the rights codified in the Charter may be interpreted to the detriment of dignity of another and that human dignity forms the core of all rights provided for by the Charter. The right to human dignity must be respected even in situations in which there are limitations upon the exercise of certain other rights. The purpose of the Charter is, among others, to consolidate the importance of dignity, in other words, the right to living in dignity, with the understanding that the quality of life may be diverging according to the socioeconomic situation in various European countries. The essence of life in dignity of a man or woman consists of a whole range of factors of existence, and the point is to appraise this right in its complex nature. It is clear that especially the wider extent of effectively enforceable social rights contributes to the higher quality and thus dignity of life.

The right to dignity is further developed in the particular European legal orders in the form of specific laws, in the Czech Republic for example the civil code (Lavický, 2014, p. 52), the criminal code (Jelínek, 2014, p. 602), or the law on discrimination (Boučková, Havelková, Koldinská, Kühn, Kühnová,Whelanová, 2010, p. 20).

1 Judgment of the Court of Justice of the EU in case C-377/98, of 9. October 2001, points $70-77$. 
Human dignity is thus an idea ${ }^{2}$ expressed in the positive law as a general concept enshrining the value protected primarily by, within the Czech legal order, the Charter of Fundamental Rights and Basic Freedoms, by the whole range of human and fundamental rights international treaties, the civil and the criminal code, all being parts to the protection of a person's integrity in its entirety.

The concept of human dignity itself was declared inviolable already in the Preamble to the Czech Charter of Fundamental Rights and Basic Freedoms. Even a law of constitutional force may not change this, because Article 9(2) of the Czech Constitution would prohibit such an amendment providing that "the substantive requisites of the democratic, law-abiding State may not be amended" (Molek, 2014; Forejtová, 2014a; Klíma, 2015a; Holländer, 2012, Kubitová, 2015). By this token, the right to human dignity should be considered as being a right of the supra-positive status, and the respect and protection to human dignity and freedom as the top and most universal (final) priority of law ${ }^{3}$. When considering the protection of human dignity, the respect it must be paid and the shield provided to it by public authorities against the interference from third persons must be the backbone of all thinking about the relationship between an individual and the power of the state on the one hand, and the horizontal relationship between private individuals on the other. As the Constitutional Court made clear in its jurisprudence, it is the guarantee of inviolability of human dignity that allows people to fully enjoy their individuality (Pavlíček, Hofmannová, 2014, p. 279-301). The effect of constitutional safeguards is even more intensive in the vertical relationships, i.e. the state versus the individual. Also judicial proceedings that may be initiated and decided by courts ex officio, so-called non-adversarial proceedings, should be considered as a kind of such vertical relationship (Zahradníková, 2013, p. 53; Zahradníková, Wipplingerová, Spurná, 2015). In other words, all matters in which the public interest prevails over the interests of private individuals. In these vertical relationships, all fundamental rights must be applied as self-executing rights directly binding the public authorities concerned. Interpretation of the rights and rules must respect the boundaries outlined by the human dignity. Because the Charter of Fundamental Rights gives those rights the status of absolute rights, they may be limited only in order to safeguard

2 It concerns a value concept which is to the certain extent evolutionary, rather than a rigid concept amenable to a precise definition.

3 Judgments of the Constitutional Court of the Czech Republic in cases No. zn. IV. ÚS 2268/07 and No. IV. ÚS 412/04. 
fundamental rights of other individuals or to protect the public interest, which is recognized by the constitutional order in forms of a principle or value 4

Human dignity must be also understood as a constant principle (Mlsna, 2010, p. 125-136) pertaining to the human being on the basis of the natural ethos of a man and woman ${ }^{5}$ Being deprived of dignity may be one way to truly appreciate human dignity. Such loss may occur in instances when an individual loses his or her socio-economic standing, because the status of a modern man and woman is today derived mainly from his or her performance, contribution to the society, or his or her social position and reputation. Human dignity is intimately related to other rights, because it materializes through the exercise of those rights and thus is enshrined in the whole range of other fundamental rights (Popovičová, 2009, p. 225-230).

\section{OVERVIEW OF THE GERMAN AND CZECH LEGISLATION ON THE RIGHT TO DIGNITY}

In the Central European context, it is fitting to provide a short overview of the legislation of the Federal Republic of Germany. The German Basic Law (the Basic Law) of 1949 declares in its very first article: Human dignity shall be inviolable. To respect and protect it shall be the duty of all state authority. Vital in this context is also Article 79(3) of the Basic Law ${ }^{6}$ providing that amendments to the Basic Law affecting the division of the Federation into Länder, their participation on principle in the legislative process, or the principles laid down in Article 1 (guarantee of protection of human dignity) and Article 20 (Germany as a democratic and social federation) shall be inadmissible.

The Basic Law (Forejtová, 2014b, p. 56) draws a very clear line between the state of affairs before year 1945, in which the constitutional principles had been but monologues of the legislator on the one hand, and on the other hand the situation after the War, in which the constitution has become the centre of gravity and the departure point for all legislation. That is why Article 1(3) of the Basic Law clearly provides that "The following basic rights shall bind the legislature,

\footnotetext{
4 Judgment of the Constitutional Court of the Czech Republic in case No. IV. ÚS 412/04.

5 Pavel Holländer comments on the express material core of the constitution as a "metaphysical correlation of the positive law", in the centre of focus of which is exactly the protection of human dignity (Holländer, 2005, p. 330-331).

6 So called Bestandssicherung, Ewikeitsgarantie, Ewigkeitklausel (Forejtová, 2014a, p. 45, 53).
} 
the executive and the judiciary as directly applicable law". In 1957, the Federal Constitutional Court commented on the issue that: "legislative power is subject to more stringent constitutional restrictions than under the Weimar Constitution of $1919 \ldots$ [T] he legislature [at that time] could modify or alter constitutional rights [at will]... The Basic Law, on the other hand, erected a value-oriented order that limits public authority. This order guarantees the self-determination, and dignity of man within the political community. The highest principles of this order of values are protected against constitutional change... Laws are not constitutional merely because they have been passed in conformity with procedural provisions... They must be substantively compatible with the highest values of a free and democratic order - i.e., the constitutional order of values - and must also conform to unwritten fundamental constitutional principles as wed as the fundamental decisions of the Basic Law, in particular the principles of the rule of law and the social welfare state. Above all, laws must not violate a person's dignity, which represents the highest value of the Basic Law; nor may they restrict a person's spiritual, political, or economic freedom in a way that would erode the essence of [personhood]"'. Already in one of its first judgments the Federal Constitutional Court has also commented on the issue thus: "It is by definition not entirely impossible, that even constitutional provisions are themselves invalid - despite being part of the text of the Basic Law. There exist such constitutional principles so fundamental and are such an emanation of law that they may take precedents even before the Basic Law, and thus are binding the authors of the Basic Law. Other provisions of the Basic law do not possess such a force as these principles, and may be invalid if in conflict with such fundamental principles"s.

Inspired by Germany, the Czech Republic emphasized the importance of human dignity in Article 1 of its Charter, according to which all people are free and equal in their dignity and rights. The basic human rights and freedoms should not be today viewed only as rights, the aim of which is to protect the individual against the state authority, but must be seen as the fundamental basis of values ${ }^{9}$ (Hofmannová, 2011, p. 57). Every person can derive from them the enforceable right to respect and recognition as a human being, which is also the

\footnotetext{
7 Judgment of the Federal Constitutional Court of Germany in case No. BVerfGE 6, 32 (41 násl.) in case Elfes.

8 Judgment of the Federal Constitutional Court of Germany in case No. BverfGE 1, 14 (32) in case Südweststaat.

9 Judgments of the Constitutional Court of the Czech Republic in cases No. Pl. ÚS 19/93; Pl. ÚS 36/01; Pl. ÚS 27/09; Pl. ÚS 19/08; 29/09 (Tomoszek, 2015, p. 3-15).
} 
source of Czech Constitutional Court's jurisprudence that humans must not become mere objects of the volonté général, and that individuals must not be treated in a way that undermines their status of holders of rights and obligations ${ }^{10 .}$

In the Czech legal order human dignity is not built up as a self-standing (selfexecuting) right, but rather as an interpretative benchmark ("a material criterion"), a value that is projected against all fundamental rights and freedoms listed in the Charter of Fundamental Rights and Basic Freedoms (be it civil, political, or social rights). I believe, however, that in case of lacuna in the constitutional framework, which could not be overcome by means of analogical interpretation, the human dignity would have to be applied directly as a self-executing right that may be enforced (Mlsna, 2011, p. 135). In support of this conclusion I refer also to the Charter of Fundamental Rights of the EU and its Article $1^{11}$.

Human dignity is thus inextricably linked to the concept of equality as the universal principle of interpretation with its discrete anti-discrimination nature (McConnachie, 2014, p. 609-629), because the key precondition of freedom and equality before the law is precisely the fulfilment of the dignity of a person (Forejtová, 2013). The equality in rights in this sense means, on the one hand, the equal access to rights, and on the other hand - the prohibition of exclusion of an individual from access to particular rights and freedoms. Aharon Barak, for example, identified four basic features of constitutional guarantee and protection of human dignity, specifically the interrelatedness with the principle of equality, free will, physical and mental well-being (i.e. the guarantee of social rights), and prohibition to treat human beings as objects (Barak, 2008, p. 86-87).

\section{PRINCIPLE OF PROPORTIONALITY AND ITS APPLICATION IN THE EXERCISE OF FUNDAMENTAL HUMAN RIGHTS}

Thus, according to the constitutional provisions, everyone has the right that his or her dignity be preserved, honour, reputation, and name protected. Limitations to these rights may normally only occur on the basis of public policy, public safety,

10 Judgment of the Constitutional Court of the Czech Republic in case No. IV. 412/04 (Güttler, 2014, p. 501- 511).

11 Article 1 of the Charter of the Fundamental Rights of the EU "Human dignity is inviolable. It must be respected and protected". 
or public health exception. Generally, human dignity means the legal safeguards against the treatment disregarding the dignity of a person as a human being, in other words, the protection against treating a man or woman inhumanly.

In constitutional law, the principle of proportionality is related with the interpretation and application of particular (colliding) fundamental rights and freedoms ${ }^{12}$. Those are, from the most part, contrived as general principles, which may be applied to a certain extent, the extent of which is defined by the impact of the other colliding principles and values. These particular principles (rights and freedoms) must be mutually reconciled and in case of collision one must take precedence, while it is necessary to minimize the impact onto the others. The principle of proportionality therefore lies in the search for an optimal balance between means and ends. This balancing must be put into practice by assessing three elements (criteria, sub-principles) - the test of appropriateness, the test of necessity, and the test of proportionality in its strict sense (Ondřejek, 2012; Kosař, 2008; Holländer, 2012, p. 219; Barak, 2012). An important feature of the proportionality principle is its general applicability ${ }^{13}$ normally to all basic rights, both under the abstract or concrete control of constitutionality, and also in the course of an individual constitutional petition procedure (Forejtová, 2014b, p. 87; Filip, 2011, p. 32-45). The application of the proportionality principle is intimately related to the teleological method of interpretation (Wintr, 2013, p. 125).

\section{COLLISION BETWEEN FUNDAMENTAL RIGHTS AND THE RISK OF SO-CALLED SOCIAL DEATH}

From the above propositions it is therefore clear that human dignity radiates into the interpretation and concept of all rights, also economic, cultural and social rights as listed in the Chapter Four of the Charter (Pokorný, 2010, p. 175-208). It

12 As the first case of use of the proportionality test by the Czech Constitutional Court is usually referred to the judgment of the Constitutional Court of the Czech Republic in case No. Pl. ÚS 4/94 (Anonymous witness). However, the very first hints of the proportionality test may be traced already in judgment No. Pl. ÚS 43/93 (Defamation of the Parliament).

13 There are countries, however, which refuse to take the three-prong proportionality test as a universal mechanism (The US Supreme Court and the American academia, which work with different tests - "rational basis test", "intermediate scrutiny" a "strict scrutiny" (Kosař, Antoš, Kühn, Vyhnánek, 2015, p. 363). 
is the interrelatedness between those rights, which has manifested in the course of one specific case, which I will describe and comment here below. The origins of the case are in the conflict between fundamental rights of a child on the one hand, and constitutionally guaranteed basic rights of a parent on the other. The story gets more complicated because it is not only about a conflict of two opposing rights, but rather a conflict of multiple rights of one individual against multiple rights of the other. The basic right of a child is, pursuant to Article 33(1) of the Charter of the Fundamental Rights and Basic Freedoms in the Czech Republic (the "Charter"), the right to education. As of result of its imprudent application, a collision may arise between the rights of parents, at least these: right to human dignity pursuant to Article 10(1) of the Charter, right to freely choose the profession pursuant to Article 26(1) of the Charter, prohibition of forced labour pursuant to Article 9(1) of the Charter, the inviolability of the person and of private life pursuant to Article 7(1) of the Charter, the right to be protected from any unauthorized intrusion into private and family life pursuant to Article 10(2) of the Charter, right to judicial and other legal protection under Article 36(1) of the Charter, and right to due process pursuant to Article 6 of the European Charter of Human Rights (Molek, 2012; Forejtová, 2014b, p. 188).

The background of the specific case which was before the Constitutional Court of the Czech Republic, and which ultimately dismissed the petition as manifestly unfounded ${ }^{14}$, begs the following question: Is it permissible that the exercise of a right of a child manifestly interferes with the constitutional rights of a parent, especially his or her right to human dignity, free choice of profession, and with the prohibition of forced labour (Klíma, 2015b, p. 88)?

Now, to the facts of the case. The petitioner had an obligation of maintenance support to his only daughter under age, imposed by a court in the amount of $2 /{ }_{3}$ of his monthly salary ${ }^{15}$. The court explained that the amount of maintenance support was calculated with regard to the particulars on the side of the child, especially high tuition fees at a prestigious high school. The parent had submitted that the maintenance should be decreased at least so that it amounts to the half of his monthly salary, arguing that his salary had gone down materially since the time of a previous court decision calculating the maintenance. The petitioner was university educated, a doctor of medicine working for the Czech Academy

14 Judgment of the Constitutional Court of the Czech Republic in case No. IV. ÚS 707/15.

15 There is no binding legislation in the Czech Republic which would provide for the amount of maintenance in relation to the level of salary. Such legislation exists in France, for example. 
of Sciences ${ }^{16}$. At the time when the petitioner had been employed with this high profile research institute, the employer received a decision initiating enforcement of a maintenance judgment against the petitioner for an alleged default with paying maintenance instalments. In the enforcement proceedings, the authorities issued in total four execution orders, by means of which petitioner's driving license was suspended, his movable assets sold, his salaries had been partially withhold and funds on his bank accounts transferred to the other parent. The conduct of the enforcement authorities apparently paralyzed the petitioner with the result of severe limitations on his ordinary way of living. On the top of that, the petitioner considered his work for the Czech Academy of Sciences as the peak of his career, although it is generally considered that research and academia are not primarily high profit activities, but they are, as profession, viewed as prestigious and respected as valuably contributing to the society. Also as a result of the enforcement, the petitioner was dismissed; or rather his employment contract was not extended by the Academy. The petitioner was thus forced to apply for social security assistance. It may seem paradoxical that general (family) court imposed on the petitioner the duty to work beside his job at the Academy of Sciences, as a self-employed businessman so that he could afford to pay for his underage daughter's elevated needs, but at the same time the court suspended his driving license, which is usually the indispensable and frequent tool necessary for conduct of many business activities. As a result of this court's decisions, the petitioner ended up in a situation in which he could not objectively perform his obligations (Hulmák, 2014, p. 1220; Švestka, Dvořák, Fiala, 2014, p. 485) being forced to conduct business on the one hand, but on the other being prohibited from driving a car that he needed for his business. Thus his daughter's standard of living significantly exceeded that of the parent (the petitioner) and the petitioner could not fully enjoy his personality, encompassing among others his right to self-determination. The right to self-determination and to the responsibility for one's own development has been found by foreign case-law as fundamental rights and freedoms, which form a barrier of citizen as against the interference

16 The main tasks of the petitioner's working and research activities were mainly: a) experimenting with animals in the area of diabetes, design of experiments and histological treatment of tissues samples, b) immunohistochemistry, c) immunocytology, d) intracellular visualisation of punctures in vivo with the help of fluorescent lentiviral conpunctures. The petitioner has regularly published in journals and expert periodicals in the course of his research. On 5.12.2014 the petitioner received from the České pneumologické a ftizeologické společnosti (Czech pneumological and ftizeological society) ČLS J.E.P. the award as the „1. best publication by authors over 35 years in 2013 ”. 
by the state ${ }^{17}$. The limitation of the petitioner's rights to protection of human dignity was imposed allegedly as a consequence of protecting the rights of an underage daughter to education at a high school, which incidentally is not even a constitutionally guaranteed right, because the right to education pursuant to Article 33 of the Charter only provides for elementary schools in the sense of compulsory education.

The petitioner's right to freely choose his profession, guaranteed by the Charter, may be exercised in principle through a self-employed business (the right to engage in commercial and economic activity pursuant to Article 26(1) of the Charter), or in an employment relationship (the right to acquire the means of her livelihood by work under Article 26(3) of the Charter) (Wagnerová et al., 2012, p. 573). The constitutional right to free choice of profession does not mean that a particular employment is guaranteed constantly and that an employment relationship may not be unilaterally cancelled. The Charter in Article 26 rather provides for a right of each person to free choice of profession, while the aim of that right is to provide a choice to each individual to decide in which area of human endeavour he or she would like to perform and apply for jobs (Wagnerová et al., 2012, p. 777). The Constitutional Court has ruled in its previous case law that an indispensable requirement for the functioning of a liberal democratic society is to create an autonomous space for individuals, in which they may freely accomplish their life among other as economic, social beings who gain their daily bread by working or otherwise being economically engaged ${ }^{18}$. The petitioner had studied for many years so that he could be employed as a researcher to achieve the top position within his particular profession. The law should corroborate the need to respect the petitioner's decision to work in academic research, also with the regard to the substantial benefits that society gains out of petitioner's work. The fact that the petitioner had not been making huge profits out of his work should not be automatically used against him.

The freedom from coercion into labour relates to the right to freely choose profession and to engage in commercial or economic activity, and the right to acquire the means of his or her livelihood by work, which are the examples of positive freedoms, from which a contrario stems a negative freedom, i.e. the prohibition of forced labour (Wagnerová et al., 2012, p. 262). By forced or obliga-

17 Judgment of the Federal Constitutional Court of Germany in case No. BVerfGE 7, 198.205, case Lüth.

18 Judgment of the Constitutional Court of the Czech Republic in case No. I. ÚS 504/03. 
tory labour we understand any and all work or service which is demanded from a person under a threat of any punishment, and for which that person has not volunteered. Constitutional Court's case law makes clear that forced labour or services correspond in their characteristics with the labour or services listed in Article 9(1) of the Charter, but that list being not exhaustive. It is usually labour or services that significantly and in a very restrictive fashion interfere with personal rights and freedoms of a citizen and the imposition of which is executed via an administrative act ${ }^{19}$. The constitutional provision on prohibition of forced labour is not strictly speaking a right, but an instruction not to coerce natural persons individually or collectively to engage in a certain activity without their freely given consent (Klíma, 2009, p. 1023). Prohibition of forced labour aims to protect human freedom and dignity in their very essence. The capacity of an individual to make a choice which profession, employment, or other activity he or she will devote the time and endeavour to, and especially in what way he or she intends to acquire the means of livelihood, is a guarantee of the sphere of freedom in the area that has a momentous importance for the development of the personality of any man and woman, and greatly impacts all aspects of their life. It is about the self-actualization of a person, a chance to consider which activity would work best for that person and what he or she herself may offer to the public.

If some authority imposes an obligation to engage in some activity, that obligation also sets the direction in which that person concerned will spend much time of his or her life, which profession he or she will engage in and what kind of remuneration he or she will receive, the amount of which will also have to be set authoritatively. All these circumstances are or may be important for the private and family life of the concerned individual, for his or her standard of living, eventually the social standing, and last but not least - for his or her own feeling of satisfaction. Such a state of affairs and eventually a position of inequality as against some other groups of persons not subject to that obligation may be viewed as degrading and thus begging the question whether his or her human dignity has not been illegally affected ${ }^{20}$.

With the right to self-determination, which is reflected among others in the right to free choice of profession, is inextricably linked the concept of inviolability of a person and his or her privacy. As the Constitutional Court posited:"[T]he

19 Judgment of the Constitutional Court of the Czech Republic in case No. Pl. ÚS 37/93.

20 Judgment of the Constitutional Court of the Czech Republic in case No. Pl. ÚS 1/12-1. 
right to protection of personal privacy is the right of a natural person to decide according to his own deliberation whether, or to what extent and in what manner, the facts of his own personal privacy are to be made accessible to other subjects, and at the same time to defend oneself against (resist) unjustified interference in that sphere by other persons. Excessive emphasis on the positive component of the right to protection of one's private life leads to inappropriately narrowing of protection to merely seeing to it that the facts of a person's private life not be [disclosed] without his consent or without reasons recognized by the law, and thus the integrity of the internal sphere, which is essential for positive personal development, not be violated. The Constitutional Court does not share this narrowed understanding, because respect for private life must, to a certain degree, include the right to form and develop relationships with other human beings. Respect for private life, thus understood, includes the commitment of the state to act in a manner that permits the normal development of these relationships" ${ }^{21}$. A person's private and family life is also constitutionally protected, because pursuant to Article 10(2) of the Charter, everyone has a right to be protected from any unauthorized intrusion into her private and family life. The right to privacy also includes a right to respect an identity and honour of a person (Wagnerová et al., 2012, p. 284).

The Constitutional Court ruled in factually similar cases"22: "the courts, when deciding on the ability to pay the due maintenance, have not taken into consideration the real means of the petitioner to be able to meet such an obligation. (...) It is obvious that the petitioner must pay the due maintenance support (in the amount set by the court), but when deciding on the due date of the debt, the duty to pay up debts must not be mistaken for a "punishment" (particularly where the obligor is willing to pay), but rather the court must respect certain criteria of proportionality, which also in the interest of beneficiaries will prevent the situation, in which the obligor will not be able to perform his obligation in the future, or would himself become a dependent on the social assistance support". The Constitutional Court made clear that in that particular case the lower courts have manifestly interfered with the right of the petitioner to human dignity by imposing an obligation of an excessive maintenance duty on him based purely on a fictional work he might theoretically be able to undertake. When ruling on the maintenance support, the courts must unquestionably respect the principle

\footnotetext{
21 Judgment of the Constitutional Court of the Czech Republic in case No. II. ÚS 517/99.
}

22 Judgment of the Constitutional Court of the Czech Republic in case No. II. ÚS 979/13. 
of proportionality as set out by Article 4(4) of the Charter. Interference with the constitutionally guaranteed rights of petitioners by disproportionate maintenance support duty is, from the petitioner's point of view, unacceptable under the rule of law. When various rights collide, it is always necessary to give protection to the right guaranteed by the constitution that is hierarchically superior to any rights only guaranteed by secondary legislation.

\section{CONCLUSION}

We may of course discuss the degree of harm to human dignity in every single case. If we compare the cases of assaults on human dignity in the environment of armed conflicts, in the state of humanitarian crisis or confinements of a refugee camp, the above described case will appear as marginal in our eyes, if not ridiculous. However, if we consider the context of the entire case and the standard of living in European countries where the Czech Republic belongs, it is clear that a man or woman may be socially and mentally destroyed even by a less "harsh" treatment than inhuman or degrading treatment prohibited by international treaties on humanitarian law.

It is vital to stress that the functioning institutions for constitutional protection (constitutional courts in the concentrated constitutional judiciary, or general courts in the system of an abstract constitutional control) (Forejtová, 2014b, p. 35) and the system of protection of human rights in European countries are primarily designed to provide protection to individual human rights. In case of collision of such rights, these institutions are summoned to decide which right should justifiably take precedence. The basic benchmark for their decisionmaking must always be, however, the respect to human dignity of each person, at least to the extent as it is set out by the Charter of Fundamental Rights of the EU. Following that standard, it is then inconceivable that these institutions of constitutional protection should resign over conducting the test of proportionality, the very test by means of which the balance between individual rights and the extent of their limitation should be sought.

In case of absence of this balancing exercise and failure to attribute respective values to the protected rights, the individual is deprived of all protection and the proceedings before the institutions become devoid of an effective remedy. Situations such as those in which one right takes unjustifiable precedence over another right thus creating an inequitable distortion of balance to the detriment 
of that right, equally protected by constitution and international law, must not be allowed. Underrating the proportional balancing of rights thus results in not minimizing the impact on the other right, but in an absolutely unacceptable interference by the state. Also the lack of reference to the relevant case law of the European Court of Human Rights ${ }^{23}$ by the national institutions for constitutional protection brings about an increase in number of petitions by individuals against the signatory state.

The rule of law means the search for a balance between individual rights, not a situation in which, as a result of judicial decision-making, an individual person is deprived of fundamental rights and freedoms, which are guaranteed by the constitutional order. When the constitutional guarantees of human dignity fail, this distorts the principle of equality and also impacts on free will, the physical and mental well-being of an individual, and to the lost of genuine warranties of social rights under the rule of law at the end of the day.

\section{ReFERENCES:}

Barak, A. (2008). The Judge in a Democracy. Princeton: Princeton University Press.

Barak, A. (2012). Proportionality. Constitutional Rights and their Limitations. Cambridge: Cambridge University Press.

Boučková, P., Havelková, B., Koldinská, K., Kühn, Z., Kühnová, E., Whelanová, M. (2010). Antidiskriminační zákon. Komentár. Praha: C.H. Beck.

Düwell, M., Braarvig, J., Brownsword, R., Mieth, D. (eds.). (2014). The Cambridge Handbook of Human Dignity: Interdisciplinary Perspective. Cambridge: Cambridge University Press.

Filip, J. (2011). Ochrana základních práv a svobod z pohledu vývoje ústavní stížnosti. In: A. Gerloch, P. Šturma (eds.), Ochrana základních práv a svobod v proměnách práva na počátku 21. století v českém, evropském a mezinárodním kontextu (p.?-?). Praha: Auditorium.

Forejtová, M. (2013). Judikatura soudů EU a Rady Evropy ve věcech zákazu diskriminace. Plzeň: Aleš Čeněk.

Forejtová, M. (2014a). Materiální ohnisko ústavy - evropské poohlédnutí. In: M. Lysý M. Považan (eds.), Premeny ústavného práva. Kontinuita a diskontinuita (p. 37-56). Bratislava: Atticum.

Forejtová, M. et al. (2014b). Ústavní soudnictví. Brno: Václav Klemm.

Forejtová, M., Tronečková, M. (2011). Evropské právo v praxi. Plzeň: Aleš Čeněk.

23 Compare with the judgment of the ECHR in case Schmidt v. Germany (Complaint no. 13580/88); Zarb Adami v. Malta (Complaint č. 17209/02); Moser v. Austria (Complaint č. 12643/02), or Weller v. Hungary (No. 44399/05). 
Güttler, V. (2014). K otázce lidských práv tzv. druhé generace a jejich reflex do ústavního práva na lidskou důstojnost. Právník, 153 (6), 501-511.

Hofmannová, H. (2011). K pojetí lidských práv v judikatuře Ústavního soudu České republiky. In: A. Gerloch, P. Šturma (eds.), Ochrana základních práv a svobod $v$ proměnách práva na počátku 21. století v českém, evropském a mezinárodním kontextu (p.?-?). Praha: Auditorium.

Holländer, P. (2005). Materiální ohnisko ústavy a diskrece ústavodárce. Právník, 144 (4), 313-336.

Holländer, P. (2012). Filosofie práva. Plzeň: Aleš Čeněk.

Hulmák, M. et al. (2014). Občanský zákoník V. Závazkové právo. Obecná část (\$17212054). Komentář. Praha: C.H.Beck.

Jelínek, J. et al. (2014). Trestní právo hmotné. Obecná část. Zvláštní část. Praha: Leges.

Klíma K. (2015a). Ústavní hodnotový systém jako "podstatné náležitosti demokratického právního státu". In: A. Švecová, M. Maslen (eds.), Rozhodovacia činnost národných, medzinárodných a európských súdov (p.?-?). Trnava: Trnavnská univerzita v Trnave.

Klíma, K. (2015b). Listina a její realizace v systému veřejného a nového soukromého práva. Praha: Wolters Kluwer.

Klíma, K. et al. (2009). Komentár k Ústavě a Listině. Plzeň: Aleš Čeněk.

Klíma, K. et al. (2011). Evropské právo. Plzeň: Aleš Čeněk.

Kmec, J., Kosař, D., Kratochvíl, J., Bobek, M. (2012). Evropská úmluva o lidských právech. Komentár. Praha: C.H. Beck.

Kosař, D. (2008). Kolize základních práv v judikatuře Ústavního soudu ČR. Jurisprudence 1, 3-19.

Kosař, D., Antoš, M., Kühn, Z., Vyhnánek, L. (2015). Ústavní právo. Casebook. Praha: Wolters Kluwer.

Kubitová, A. (2015). Dokud nás revoluce nerozdělí. In: M. Antoš, J. Wintr (eds.). Ústavní teorie (p.?-?). Praha: Univerzita Karlova v Praze, Právnická fakulta (in the press).

Lavický, P. et al. (2014). Občanský zákoník I. Obecná část 1-654. Komentář. Praha: C.H. Beck.

McConnachie Ch. (2014). Human Dignity, 'Unfair Discrimination' and Guidance. Oxford Journal of Legal Studies, 34 (3), 609-629.

Mlsna, P. (2010). Lidská důstojnost jako esenciální ústavní princip. In: L. Jirásek (ed.), Listina a současnost (p. 125-136). Olomouc: Iuridicum Olomoucense.

Mlsna, P. (2011). Lidská důstojnost a sociální stát. In: A. Gerloch, P. Šturma (eds.), Ochrana základních práv a svobod v proměnách práva na počátku 21. století v českém, evropském a mezinárodním kontextu (p. 126-136). Praha: Auditorium.

Molek, P. (2012). Právo na spravedlivý proces. Praha: Wolters Kluwer.

Molek, P. (2014). Materiální ohnisko ústavy: věčný limit evropské integrace? Brno: Masarykova univerzita.

Neal, M. (2014). Respect for Human Dignity as 'Substantive Basic Norm'. International Journal of Law in Context, 10 (1), 26-46.

Novotný, O. et al. (2014). Trestní právo hmotné. Praha: Wolters Kluwer. 
Ondřejek, P. (2012). Princip proporcionality a jeho role při kolizi základních práv a svobod. Praha: Leges.

Pavlíček, V., Hofmannová, H. et al. (2014). Občanská a lidská práva v současné době. Praha: Auditorium.

Pokorný, R. (2010). Postavení sociálních práv v Listině a jeho ústavněprávní důsledky. In: J. Jirásek (ed.), Listina a současnost (p. 175-208). Olomouc: Iuridicum Olomoucense.

Popovičová, D. (2009). Lidská důstojnost jako filosoficko-právní pojem. Časopis pro právní vědu a praxi, 17 (3), 225-230.

Radbruch, G. (2012). O napětí mezi účely práva (překlad Libora Hanuše s predmluvou Pavla Holländera). Praha: Wolters Kluwer.

Repík, B. (2002). Evropská úmluva o lidských právech a trestní právo. Praha: Orac.

Schultziner, D., Carmi, G.E. (2014). Human Dignity in National Constitutions: Functions, Promises and Dangers. The American Journal of Comparative Law, 62 (2), 461-490. DOI: 10.5131/ajcl.2013.0003, 2014.

Švestka, J., Dvořák, J., Fiala, J. et al. (2014). Občanský zákoník - Komentář - Svazek V (relativní majetková práva 1. část). Praha: Wolters Kluwer.

Tomášek, M., Týč, M. et al. (2013). Právo Evropské unie. Praha: Leges.

Tomoszek, M. (2015). Esenciální obsah základních práv jako součást podstatných náležitostí demokratického právního státu. Jurisprudence 2, 3-15.

Wagnerová, E., Šimíček, V., Langášek, T., Pospíšil, I. et al. (2012). Listina základních práv a svobod. Komentár. Praha: Wolters Kluwer.

Wintr, J. (2013). Metody a zásady interpretace práva. Praha: Auditorium.

Zahradníková, R. et al. (2013). Civilní právo procesní. Plzeň: Aleš Čeněk.

Zahradníková, R., Wipplingerová, M., Spurná, K. (2015). Zvláštní řizení soudní. Praha: Wolters Kluwer. 